Received $\quad 10.10 .2017$ Reviewed 18.12.2017 Accepted 28.12.2017

A - study design

B - data collection

C - statistical analysis

D - data interpretation

$\mathbf{E}$ - manuscript preparation

F - literature search

\section{Quantification and study of monthly variation of suspended sediment loads in Tafna basin - Algeria}

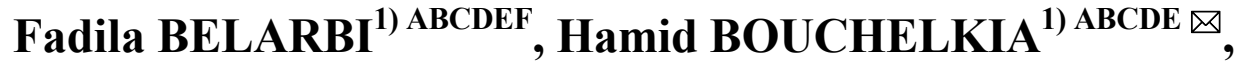 \\ Boualem REMINI $^{2)}$ ACDE , Abdelhalim BENMANSOUR ${ }^{1) \text { ACDE }}$
}

\footnotetext{
${ }^{1)}$ University of Tlemcen, Department of Hydraulic, URMER Laboratory, BP 230, 13000 Chetouane, Tlemcen, Algeria; e-mail: fabelarbi@yahoo.fr,h_bouchelkia@yahoo.fr, halim_benmansou@yahoo.fr

${ }^{2)}$ Blida University, Department of Water Science, Larhyss Laboratory, Blida, Algeria; e-mail: reminib@yahoo.fr
}

For citation: Belarbi F., Bouchelkia H., Remini B., Benmansour A. 2018. Quantification and study of monthly variation of suspended sediment loads in Tafna basin - Algeria. Journal of Water and Land Development. No. 37 p. 29 38. DOI: 10.2478/jwld-2018-0022.

\begin{abstract}
The magnitude of the phenomenon is disproportionate in semi-arid or in temperate climates. Thus Algeria is one of the most affected countries by this phenomenon and its consequences. To enable a rapid response to the request of engineers and managers to quantify sediment transport at the outlet of a watershed, a simple, easy tool to implement was developed. The principle adopted is based on hydrometric data sets from gauging stations with seasonal and annual time steps to define a suitable method for estimating sediment production. The sediment study was conducted by analysing the daily flows. Pierre du Chat station at the outlet of the Tafna basin served as an application. The obtained results are entirely satisfactory because the correlation coefficients of model $Q_{s}=f(Q)$ range between 72 and $95 \%$. This method, once refined can be generalized to all watersheds in northern Algeria.
\end{abstract}

Key words: erosion, sediment transport, statistics, suspension, Tafna basin, watershed

\section{INTRODUCTION}

Algeria is a semi-arid country and even arid (200-400 $\mathrm{mm}$ of rain per year) and renewable water resources are low, irregular and located mostly in the coastal strip [DEMMAK 1982]. With a specific erosion rates between 2000 and $4000 \mathrm{Mg} \cdot \mathrm{km}^{-2} \cdot \mathrm{yr}^{-1}$, water infrastructure of Algeria is cut with a capacity of $45 \cdot 10^{6} \mathrm{~m}^{3}$ [REMINI 1997; 2004; REMINI et al. 2009] due to silting. Unfortunately, problems of erosion and sediment transport can reach a magnitude likely completely sterilizing the development efforts of the rivers of water management authorities.

Since Algeria is a country more affected by the phenomenon of erosion and sediment transport in rivers, several researchers have studied it in previous years [ACHITE, MEDDI 2004; 2005; ACHITE, OUILLON 2007; ARABI 1991; BALLA et al. 2016; BERGHOUT,
MedDi 2016; BouCHELKIA et al. 2013; 2014; BoUCHELKIA, REMINI 2003; BOUZERIA et al. 2017; DEMMAK 1982; ELAHCENE et al. 2013; ELAHCENE, REMINI 2009; GHENIM et al. 2008; GLIZ et al. 2015; REMINI et al. 2015; SELMI, KCHANCHOUL 2016; TACHI et al. 2016; TERFOUS et al. 2001], the phenomenon remains poorly understood and weakly mastered.

A description sediment yield of some studies undertaken in some Algerian watersheds is given in Table 1.

Quantification of suspended sediment transport at the outlet of a watershed is assessed so important that a simple and easy tool was developed in this study. The principle adopted is based on analysis of hydrometric data set gathered from gauging stations with a particular analysis of solid contributions at the monthly scale. This allowed to define an appropriate method to estimate the sediment yield. This study is 
Table 1. Sediment yield of some Algerian basins

\begin{tabular}{|l|l|r|c|}
\hline \multicolumn{1}{|c|}{ Reference } & \multicolumn{1}{|c|}{ Basin } & $\begin{array}{c}\text { Basin } \\
\text { area } \\
\mathrm{km}^{2}\end{array}$ & $\begin{array}{c}\text { Sediment } \\
\text { yield } \\
\mathrm{t} \cdot \mathrm{km}^{-2} \cdot \mathrm{yr}^{-1}\end{array}$ \\
\hline DEMMAK [1982] & $\begin{array}{l}\text { Coastal } \\
\text { Dahra }\end{array}$ & 16 & 4000 \\
\hline MEGNOUNIF et al. [2007] & Sebdou & 256 & 1047 \\
\hline ACHITE, OUILLON [2007] & Abd & 2480 & 136 \\
\hline GHENIM et al. [2008] & Mouilah & 2650 & 165.3 \\
\hline BOUCHELKIA et al. [2011] & Mouilah & 2650 & $17.73-28.41$ \\
\hline KHANCHOUL et al. [2012] & Cherf & 1710 & 350 \\
\hline MADANI CHERIF et al. [2012] & Taria & 1365 & 236 \\
\hline ELAHCENE et al. [2013] & Bellah & 55 & 610 \\
\hline BOUCHELKIA et al. [2014] & Chellif & 43700 & $53.77-94.2$ \\
\hline SELMI, KHANCHOUL [2016] & Mellegue & 7847 & 589.23 \\
\hline BALLA et al. [2017] & Reboa & 328 & 678 \\
\hline BALLA et al. [2017] & Soultez & 207 & 575 \\
\hline
\end{tabular}

Source: own study.

aiming evaluating the suspended sediment transport in the Tafna basin and study the variation of monthly production sediments.

\section{GENERAL APPROACH}

The method of this study was inspired by the published work of UNESCO [1986] it presents the interest of an estimation of the solid contributions not only from the liquid discharges but also from the frequencies of each discharges, because a weak but frequent flow can bring more sediment than a higher flow less frequent [UNESCO 1986]. In addition, the majority of researchers have clearly confirmed in their studies the influence of seasons on sediment yield in the Algerian basins, hence the interest of refining the estimation to the monthly scale.

It is expected according to the following plan:

1) collection of data contributing to the phenomenon (liquid discharge, concentrations):

a) one file of mean daily liquid discharges (rather long series without gaps);

b) one file of pairs values (liquid flow rate, concentration) as long as possible;

2) construction data files for each month;

3) statistical treatment of data;

4) determining appropriate monthly models $Q_{s}=f(Q)$ between liquid and solid flow rates;

5) study of liquid flow regimes of rivers by frequency analysis (cumulative frequency curves) for each month;

6) estimate of the monthly suspended sediment load by the combination of model $Q_{s}=f(Q)$ and the cumulative frequency curve of the liquid discharges;

7) estimate of inter-annual solid contribution mean by summing monthly loads [BOUCHELKIA 2009; BOUCHELKIA et al. 2013; 2014].

\section{EVALUATION OF SUSPEND SEDIMENT LOAD}

Once the models linking liquid flows to suspended solid flows were defined and the cumulative frequency curves of mean daily liquid discharges were erected for every month, the estimate of the mass of suspended sediment is done according to the following steps:

1) division of cumulative frequency curve of liquid flows into several frequencies intervals $\left[f_{i}, f_{i+1}\right]$;

2 ) determination of liquid flow rates $Q_{1}$ achieved or exceeded corresponding to the median of each frequency interval;

3) for each liquid flow $Q_{\text {I }}$ we calculate the sediment discharge $Q_{s i}$ using the statistical model $Q_{s}=f(Q)$;

4) evaluation of inter-annual average sediment discharge by: $Q_{s m}=\sum_{i=1}^{n} Q_{s i}\left(f_{i+1}-f_{i}\right) \quad$ [BoUCHELKIA 2009; BOUCHELKIA et al. 2013; 2014].

Two types of files were used:

- one file of mean daily liquid discharges as long as possible, complete and without gaps for the determination of tables cumulative frequency (frequency analysis of mean daily liquid discharges);

- one file of pairs values $\left(Q, Q_{s}\right), Q$ is mean daily liquid discharge.

\section{PRESENTATION OF TAFNA BASIN AND USED DATA}

The catchment of the Tafna is located in the extreme North-West of Algeria. The area of $6900 \mathrm{~km}^{2}$ is crossed by one of the largest wadi in the western countries: Wadi Tafna, flows from West to East, from Morocco to the Mediterranean Sea (near Beni Saf), the length of the main channel is $170 \mathrm{~km}$ [ZETTAM et al. 2017] (Fig. 1).

This region is dominated by the massive Jurassic mounts of Tlemcen, composed of very resistant dolomitic limestone. Culminating at $1843 \mathrm{~m}$ a.s.l. at Jebel Tenouchfi, the basin is bounded by the principal

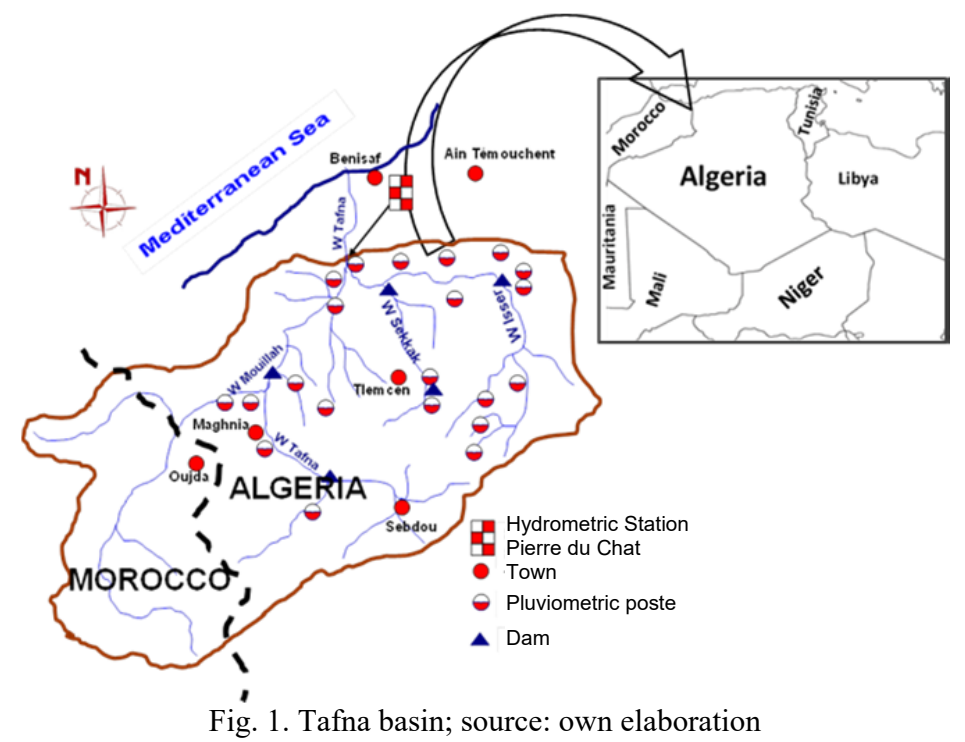


relief (Tlemcen Mountains) between the Mediterranean and the high plains of Oran and relayed to the west by the Middle Atlas of Morocco and to the east by the mountains of Daia (Saida). The basin consists principally in the south of a WSE-ENE oriented mountainous bar (800-1400 m), while the plains areas of Maghnia, of Hannaya and of Sidi Abdelli are largely dominating in the north. This orographic structure, dominated in the north by the mounts of Traras (1081 $\mathrm{m}$ a.s.1.) of small width, results in an effective barrier for precipitation, which explains the aridity of the plain of Maghnia. In $75 \mathrm{~km}$ as the crow flies, we pass from semi-arid domain to humid Mediterranean domain, from a mountainous area to a relatively flat area [BELARBI 2010].

The hydrographic network of the Tafna River mainly consists of two arteries: Wadi Tafna in the west and Wadi Isser in the East, it takes its source in the mountains of Tlemcen.

The soils of the Tafna basin consist of four major groups:

- the alluvial soil covering the low terraces and floodplains of the wadis;

- the stony land in the foothills of the mounts of Tlemcen and of Traras;

- the red soils crust, localized in the plains of Maghnia and Ouled Riah;

- Marly lands, covering much of the region of Tlemcen [BOUANANI 2005].

The vegetation is a key factor in rapid surface runoff, evaporation rate and the retention basin. So the presence of vegetation will act as a regulator in the flow regime [BOUANANI 2005].

The Figure 2 built by ZETTAM et al. [2017] shows digital elevation model with a $30 \mathrm{~m} \times 30 \mathrm{~m}$ resolution from the US Geological Survey using and a soil map a SWAT model.

The collection of data consists in a systematic analysis of parameters: depth of water and concentration of solid particles collected at the Pierre du Chat station situated on the Tafna River at the outlet of the basin, these data are from the Agence Nationale des Ressources Hydrauliques (ANRH - ang. National Agency of Hydraulic Resources).

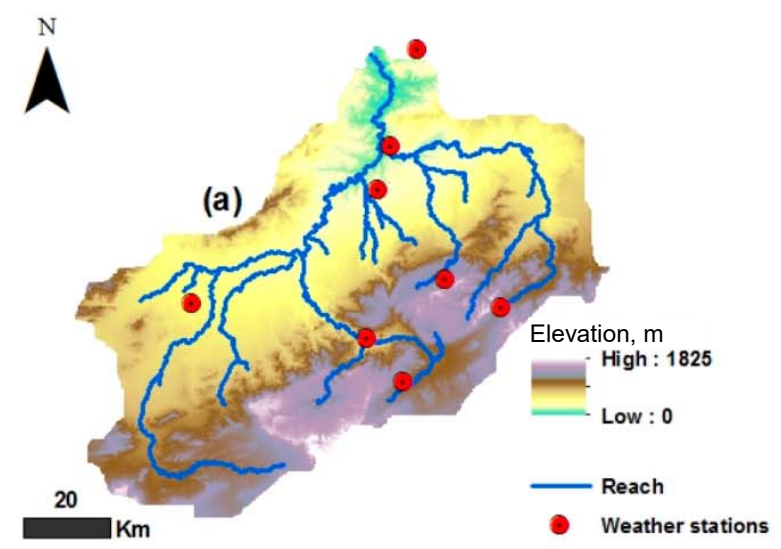

Data are representative as they extend over a period of 16 years (1990-2006) for the discharge "this data series is complete and without gaps" and over a period of 15 years (1997-2011) for the pair liquid discharge, solids discharge $\left(Q, Q_{s}\right)$.

The ANRH data were divided into two files: a file of the average daily liquid discharge without flaw and a second file for fluid flow means instantaneous and instantaneous solid concentrations observed by the ANRH services over the period mentioned above, where we have produced the file of the pair liquid discharge/solid discharge expressed as average daily discharge.

\section{EVALUATION OF SUSPENDED SEDIMENT CONTRIBUTIONS}

For Pierre du Chat station; considering the sensual influence on the phenomenon of sediment transport, applications in monthly scale have been conducted. So we established relationships between liquid discharge and sediment discharge and estimate the resulting suspension sediment loads for each month.

Over 5840 data of mean daily liquid discharge and 1320 pairs $\left(Q, Q_{s}\right)$ were selected on the period 1997-2011 in this study. It should be noted that the series of average daily water discharge is a continuous series without gaps, but the couples series $\left(Q, Q_{s}\right)$ should be as long as possible but not necessarily continuous. Figure 3 shows the monthly relationship between solid discharges and liquid flow rates. It is interesting to see that the point cloud takes the form of a power relationship: $Q=K \cdot Q^{A}$ with $K$ and $A$ are coefficients. This power model has been already proposed in 1895 by Kennedy [LEFORT 1992].

Table 2 summarizes the different relationships and correlation coefficients.

\section{Frequencial study of liquids discharge}

Using the distribution of statistical observations in classes, we were able to trace the flow duration curves (cumulative frequency of mean daily liquid discharge) [CHOW 1988; MUSY 1998] for each month of the year, so then each file of mean daily liquid

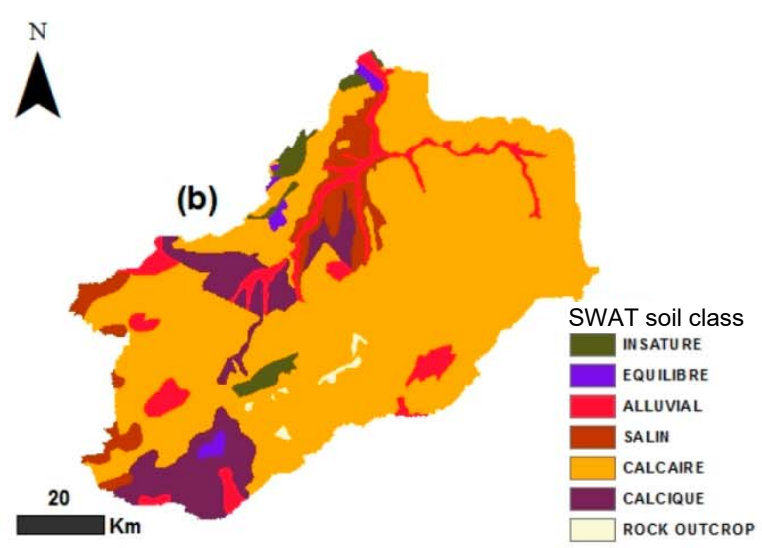

Fig. 2. Tafna basin: a) $30 \mathrm{~m}$ digital elevation model; b) main soils; source: ZETTAM et al. [2017] 

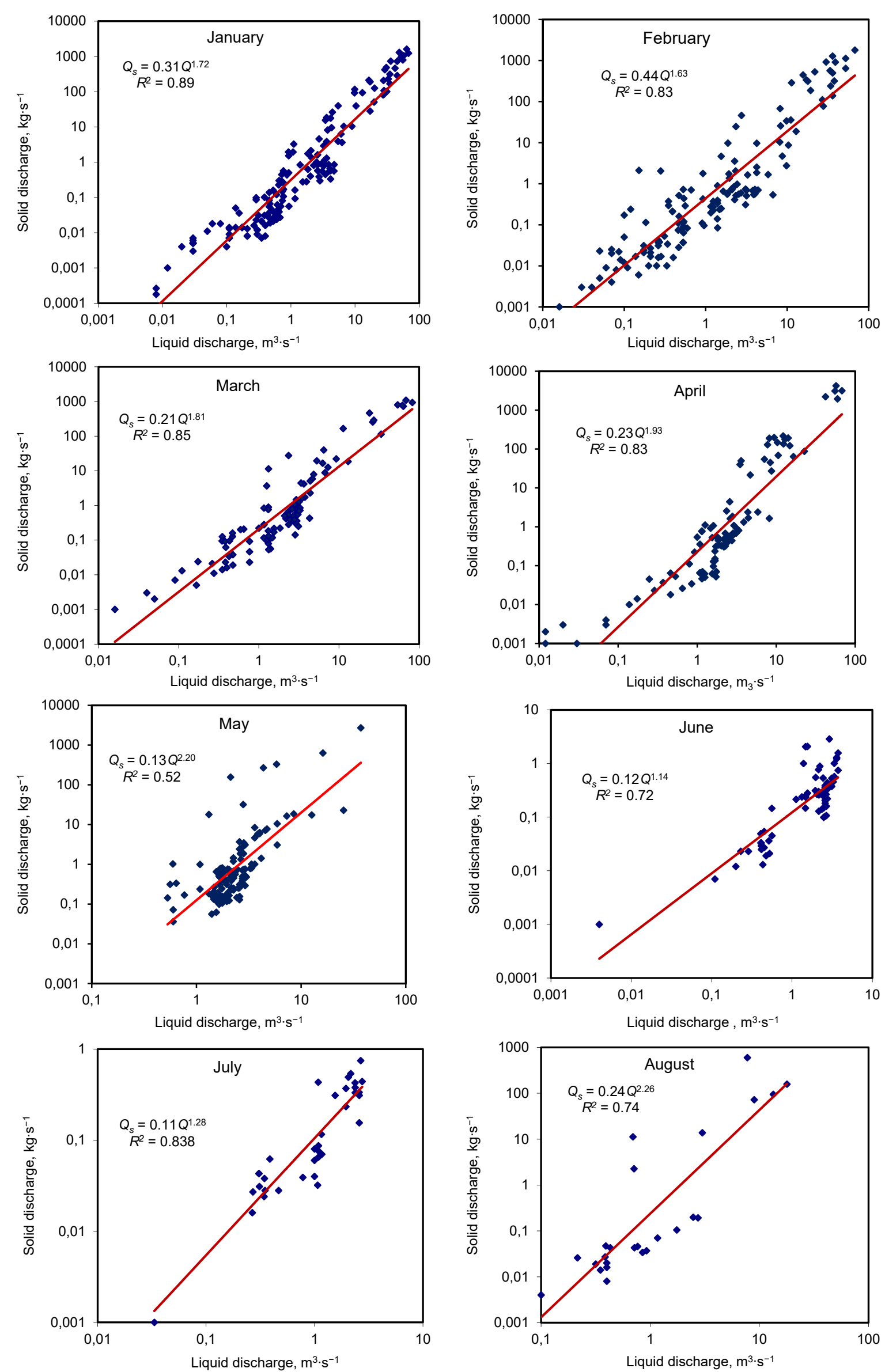

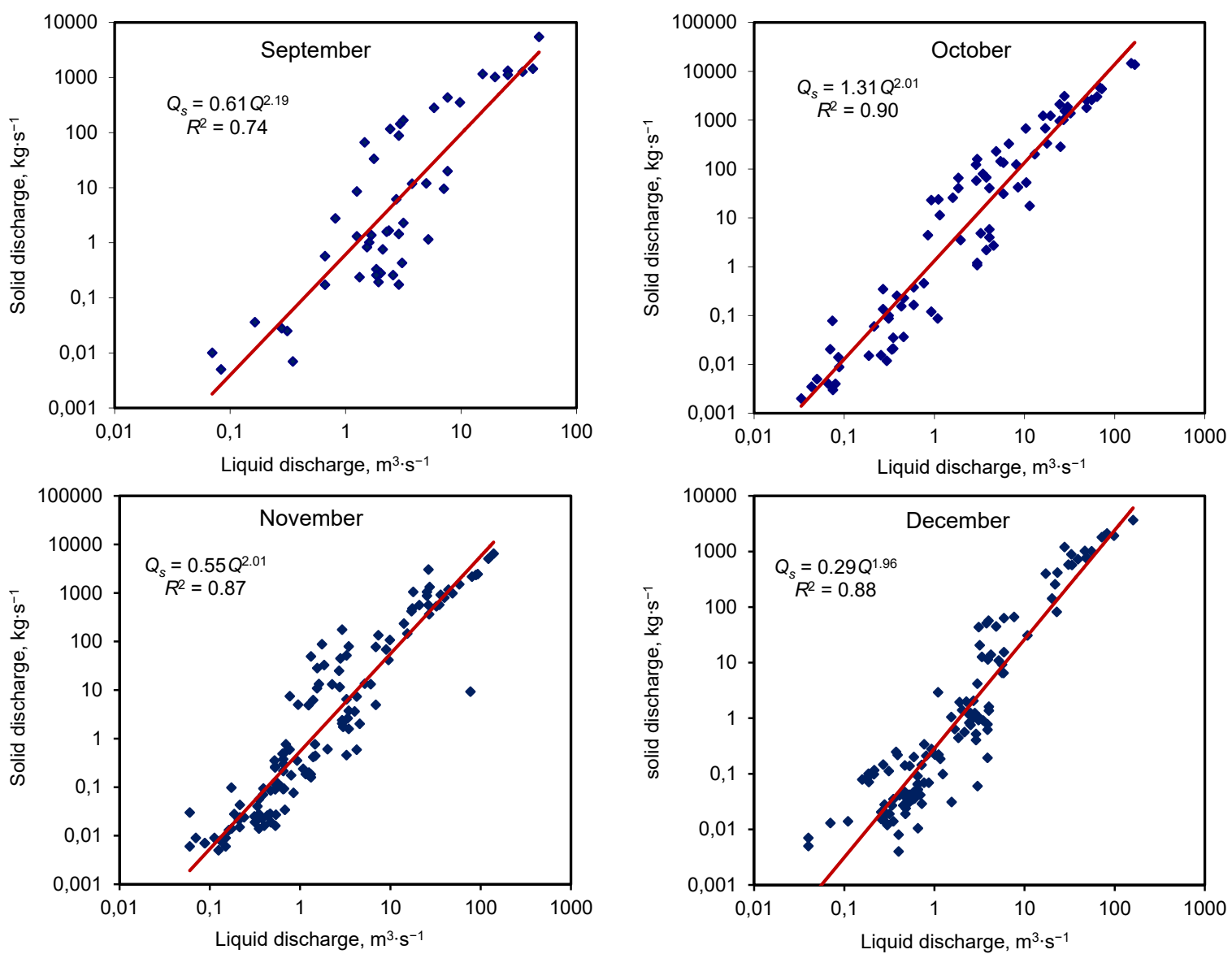

Fig. 3. Monthly correlation between solid discharge and liquid discharge; source: own study

Table 2. Monthly relationships $Q_{s}=f(Q)$ and their correlation coefficients

\begin{tabular}{|l|c|c|c|c|c|c|}
\hline \multicolumn{1}{|c|}{ Period } & Number of pairs & Coefficient $A$ & Coefficient $K$ & $\begin{array}{c}\text { Correlation } \\
\text { coefficient, } \%\end{array}$ & Relationship & Prediction interval \\
\hline January & 165 & 1.72 & 0.31 & $94 \%$ & $0.31 Q^{1.72}$ & \pm 11.33 \\
\hline February & 141 & 1.63 & 0.44 & $91 \%$ & $0.44 Q^{1.63}$ & \pm 14.89 \\
\hline March & 102 & 1.81 & 0.21 & $92 \%$ & $0.21 Q^{1.81}$ & \pm 09.87 \\
\hline April & 103 & 1.93 & 0.23 & $91 \%$ & $0.23 Q^{1.93}$ & \pm 16.60 \\
\hline May & 113 & 2.20 & 0.13 & $72 \%$ & $0.13 Q^{2.20}$ & \pm 15.39 \\
\hline June & 70 & 1.14 & 0.12 & $85 \%$ & $0.12 Q^{1.14}$ & \pm 04.83 \\
\hline July & 35 & 1.28 & 0.11 & $92 \%$ & $0.11 Q^{1.28}$ & \pm 03.06 \\
\hline August & 25 & 2.26 & 0.24 & $86 \%$ & $0.24 Q^{2.26}$ & \pm 30.42 \\
\hline September & 49 & 2.19 & 0.61 & $86 \%$ & $0.61 Q^{2.19}$ & \pm 35.95 \\
\hline October & 82 & 2.01 & 1.31 & $95 \%$ & $1.31 Q^{2.01}$ & \pm 16.81 \\
\hline November & 82 & 2.01 & 0.55 & $95 \%$ & $0.55 Q^{2.01}$ & \pm 16.75 \\
\hline December & 132 & 1.96 & 0.29 & $94 \%$ & $0.29 Q^{1.96}$ & \pm 12.33 \\
\hline
\end{tabular}

Source: own study.

discharge is classified and we determine the experimental frequencies of their discharges. For the periods considered the curves obtained are illustrated in Figure 4 . When plotting the cumulative frequency curves we observed that these curves stick to axes; they are all perfectly normal because Wadi Tafna like most Algerian wadis (rivers) is not permanent and is very irregular; its flow is low, sometimes well dry but can exceptionally reach phenomenal flows $\left(1040 \mathrm{~m}^{3} \cdot \mathrm{s}^{-1}\right.$ registered in the period 1990-2006) especially during floods, for this reason that we have borne the abscissa axis in logarithmic scale for better visibility of curves.
Table 3 summarizes the means and standard deviations of monthly average flow rates for each period. Mean and standard deviation gives us an idea about sample, standard deviation measures the dispersion of data around their mean. If the standard deviation is low, there is a concentration of data around the mean [BOWKER 1965]. So for our case the liquid flows are more concentrated around their average almost all months (standard deviation <6.28) except for the month of March where they are more dispersed around their average annual $(S D=57.43)$. 

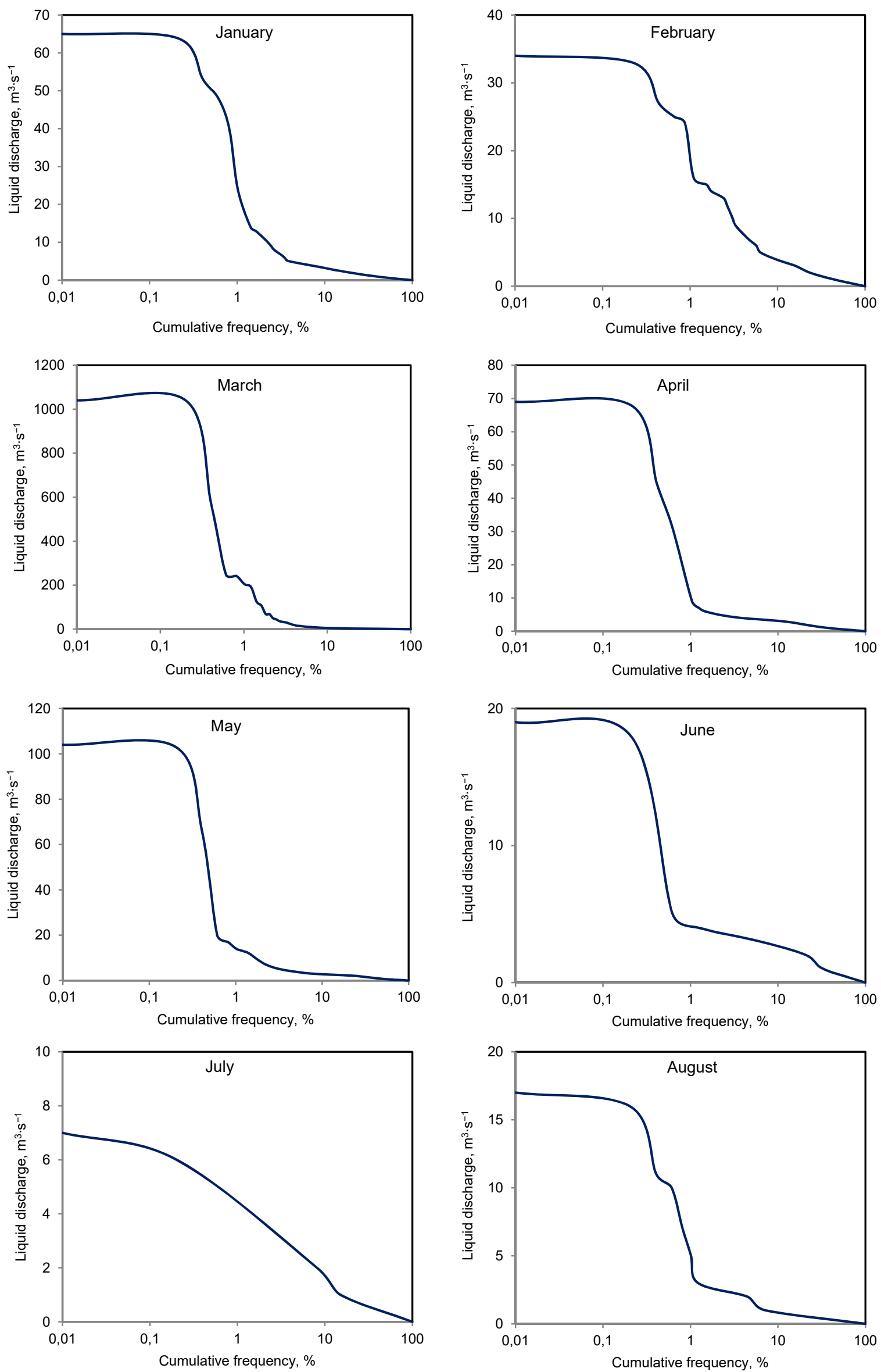

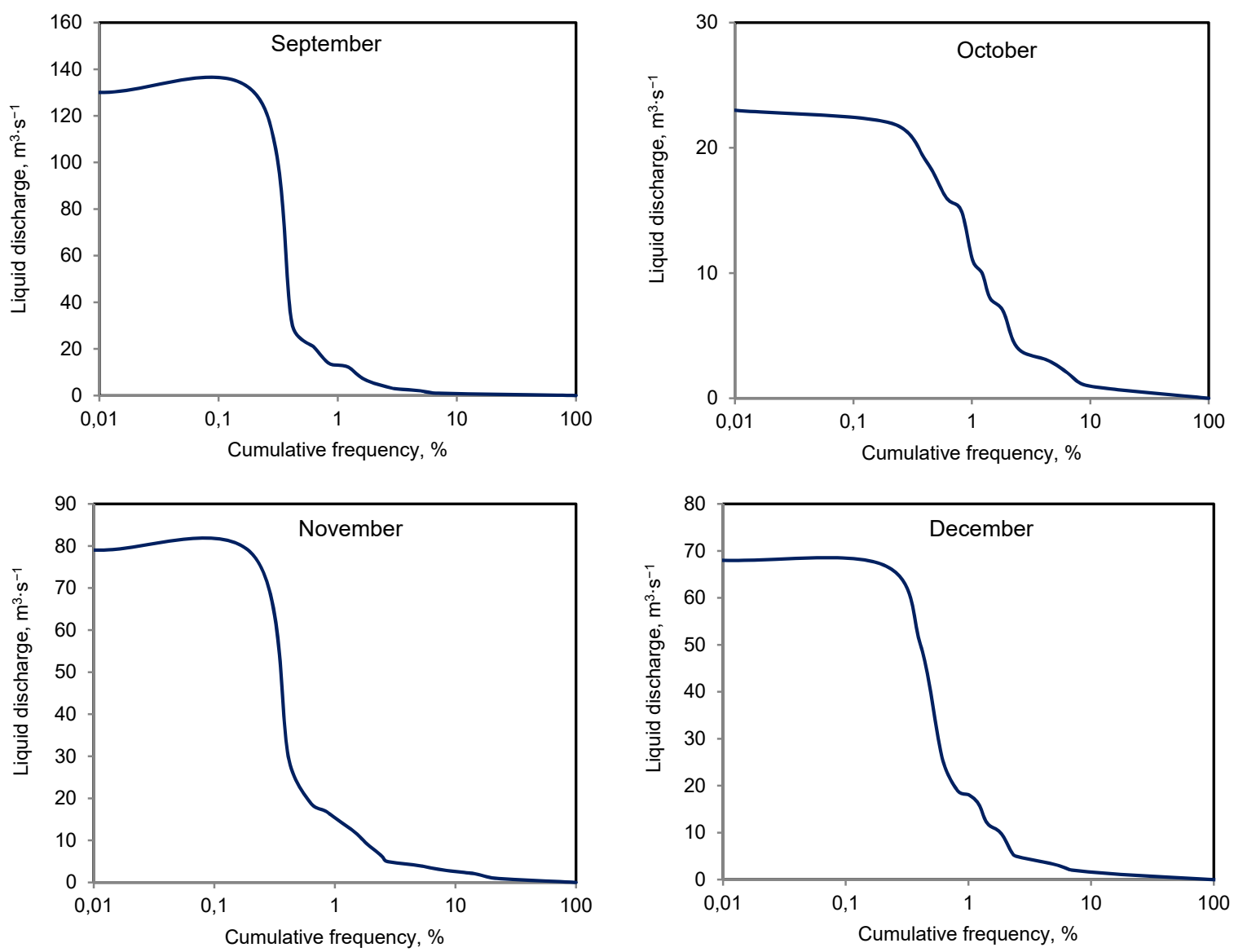

Fig. 4. Cumulative frequency curve of mean daily liquid discharge in monthly scale, station of Pierre du Chat (1990-2006); source: own study

Table 3. Means and standard deviations $(S D)$ of mean daily liquid discharge

\begin{tabular}{|l|c|c|c|}
\hline \multicolumn{1}{|c|}{ Period } & Size of sample & $\begin{array}{c}\text { Average } \\
\mathrm{m}^{3} \cdot \mathrm{s}^{-1}\end{array}$ & $\begin{array}{c}\text { Standard } \\
\text { deviation }\end{array}$ \\
\hline January & 492 & 1.76 & 5.06 \\
\hline February & 456 & 1.80 & 3.42 \\
\hline March & 492 & 8.19 & 57.43 \\
\hline April & 480 & 1.29 & 4.14 \\
\hline May & 492 & 1.57 & 5.84 \\
\hline Jun & 480 & 0.85 & 1.42 \\
\hline July & 492 & 0.33 & 0.77 \\
\hline August & 492 & 0.27 & 1.20 \\
\hline September & 480 & 0.65 & 6.27 \\
\hline October & 492 & 0.48 & 2.00 \\
\hline November & 480 & 1.08 & 4.27 \\
\hline December & 492 & 1.13 & 4.30 \\
\hline
\end{tabular}

Source: own study.

\section{Suspended sediment load}

Month by month, the model $Q=K \cdot Q^{A}$ combined with the corresponding cumulative frequency curve, has allows us to estimate average suspended sediment discharge in the considered month and that allowed us to determine the resulting monthly contributions and afterwards the inter-annual average intake is deducted by summation of the monthly intakes $\left(A s_{A}=\sum_{n=1}^{12} A s_{i}\right)$. The obtained results are presented in Table 4.
Table 4. Liquid and solid contributions of Tafna basin

\begin{tabular}{|c|c|c|c|c|c|c|c|c|c|c|c|c|}
\hline Period & 悹 & 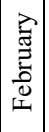 & 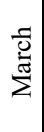 & 焉 & $\stackrel{\Xi}{\Sigma}$ & $\Xi$ & 를 & 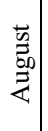 & $\begin{array}{l}\dot{\overline{0}} \\
\bar{\Xi} \\
\bar{\Xi} \\
\stackrel{0}{0} \\
\tilde{n}\end{array}$ & $\begin{array}{l}\dot{1} \\
\stackrel{0}{0} \\
0 \\
0\end{array}$ & 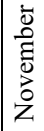 & 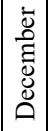 \\
\hline $\begin{array}{l}\text { Daily water dis- } \\
\text { charge average } \\
\mathrm{m}^{3} \cdot \mathrm{s}^{-1}\end{array}$ & 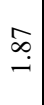 & 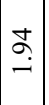 & $\stackrel{\tilde{m}}{a}$ & $\underset{\sigma}{-}$ & $\left|\begin{array}{l}\infty \\
\infty \\
- \\
-\end{array}\right|$ & $\Xi$ & $\left|\begin{array}{l}0 \\
\infty \\
0 \\
0\end{array}\right|$ & $\vec{r}$ & $\stackrel{\text { İ }}{-}$ & $\begin{array}{l}\stackrel{2}{a} \\
\grave{0}\end{array}$ & $\stackrel{\overbrace{}}{\stackrel{f}{-}}$ & $\stackrel{\sim}{\sim}$ \\
\hline $\begin{array}{l}\text { Specific concentra- } \\
\text { tion } \\
\mathrm{g} \cdot \mathrm{dm}^{-3}\end{array}$ & $\begin{array}{l}\dot{J} \\
\dot{i}\end{array}$ & 吕 & $\begin{array}{l}n \\
\infty \\
\dot{0} \\
\sim\end{array}$ & $\begin{array}{c}\bar{\sigma} \\
\stackrel{i}{i}\end{array} \mid$ & $\frac{m}{r}$ & $\frac{m}{0}$ & $\frac{N}{0}$ & $\stackrel{\infty}{\circ}$ & $\begin{array}{l}n \\
\infty \\
i \\
\sigma\end{array}$ & $\stackrel{\infty}{\sim}$ & $\begin{array}{l}n \\
\ddot{n} \\
\sim\end{array}$ & $\begin{array}{l}\text { 于े } \\
\text { f }\end{array}$ \\
\hline $\begin{array}{l}\text { Suspended sediment } \\
\text { discharge } \\
\mathrm{kg} \cdot \mathrm{s}^{-1}\end{array}$ & $\begin{array}{l}\vec{\infty} \\
\dot{m}\end{array}$ & $\begin{array}{l}N \\
\infty \\
\sim\end{array} \mid$ & 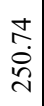 & $\begin{array}{l}\partial \\
\dot{\nabla}\end{array}$ & $\begin{array}{l}0 \\
\stackrel{9}{+} \\
\dot{2} \\
\end{array}$ & $\left|\begin{array}{l}0 \\
\hdashline \\
0\end{array}\right|$ & $\left|\begin{array}{l}0 \\
0 \\
0\end{array}\right|$ & $\frac{0}{0}$ & $\begin{array}{l}\hat{\sigma} \\
\dot{0}\end{array}$ & 守. & $\begin{array}{l}\stackrel{n}{n} \\
m \\
m\end{array}$ & $\begin{array}{l}\sigma \\
\hat{n}\end{array}$ \\
\hline $\begin{array}{l}\text { Solid contribution } \\
10^{3} \mathrm{Mg} \text { in month }\end{array}$ & 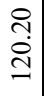 & $\begin{array}{c}\vec{\infty} \\
\dot{0}\end{array}$ & $\frac{\mathfrak{n}}{i}$ & $\begin{array}{l}\hat{\infty} \\
0 \\
0\end{array}$ & $\begin{array}{l}\circ \\
\text { in } \\
\text { in }\end{array}$ & $\begin{array}{l}\vec{t} \\
\dot{0}\end{array}$ & $\stackrel{N}{0}$ & $\begin{array}{l}\stackrel{n}{c} \\
i\end{array}$ & $\begin{array}{l}m \\
\stackrel{m}{\infty} \\
\stackrel{0}{-}\end{array}$ & $\stackrel{?}{\check{I}}$ & $\begin{array}{l}\infty \\
\infty \\
\dot{\infty} \\
\infty\end{array}$ & \begin{tabular}{l}
$\infty$ \\
$\infty$ \\
$i$ \\
\hdashline
\end{tabular} \\
\hline $\begin{array}{l}\text { Solid annually input } \\
10^{6} \mathrm{Mg} \cdot \mathrm{yr}^{-1}\end{array}$ & \multicolumn{12}{|c|}{1.17} \\
\hline $\begin{array}{l}\text { Specific degrada- } \\
\text { tion } \\
\mathrm{Mg} \cdot \mathrm{km}^{-2} \cdot \mathrm{yr}^{-1}\end{array}$ & \multicolumn{12}{|c|}{196.11} \\
\hline
\end{tabular}

Source: own study.

Figures 5, 6 and 7 summarize the variations monthly contributions of sediment yield and of liquid rates and of solid concentrations of Wadi Tafna. 


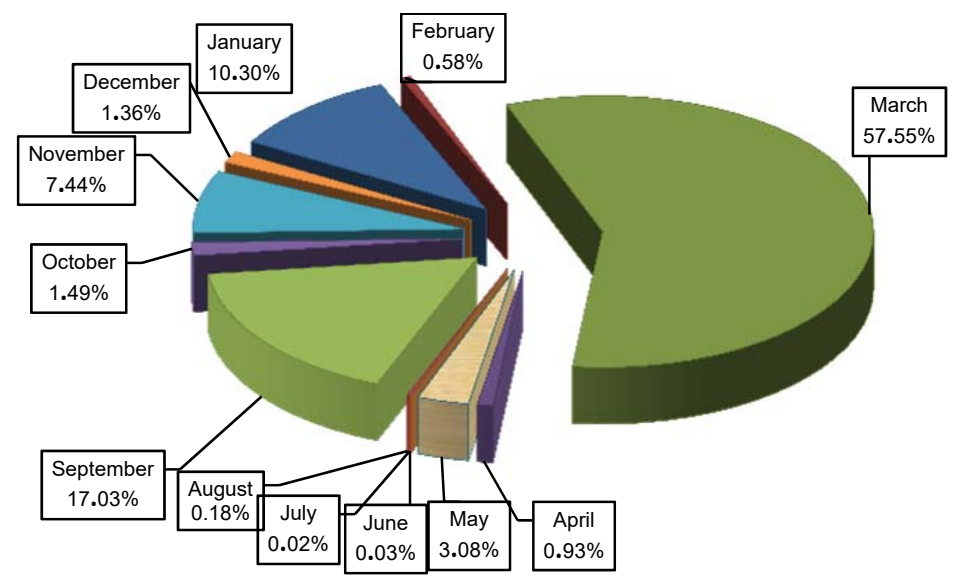

Fig. 5. Monthly contributions of sediment yield in Tafna basin; source: own study

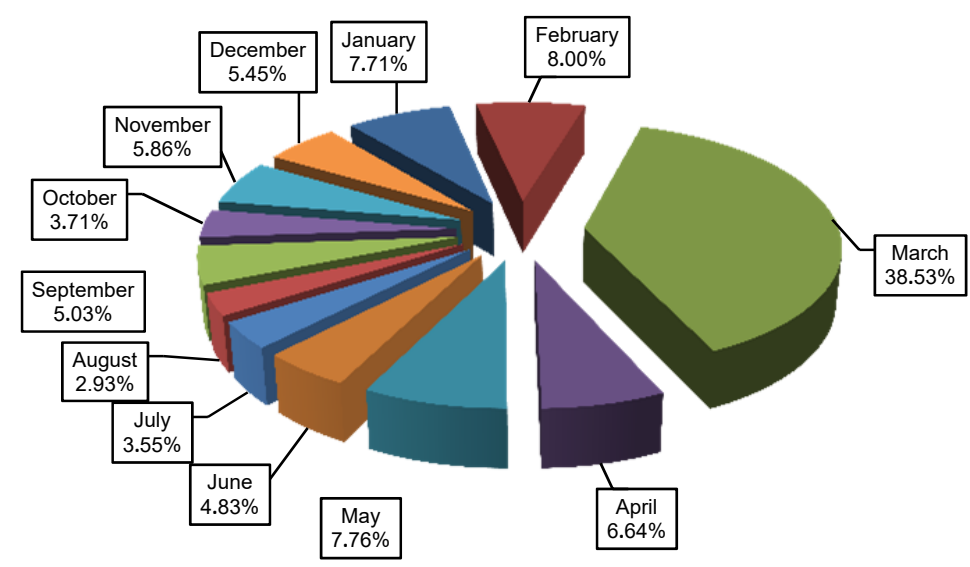

Fig. 6. Monthly contributions of liquid rate in Tafna basin; source: own study

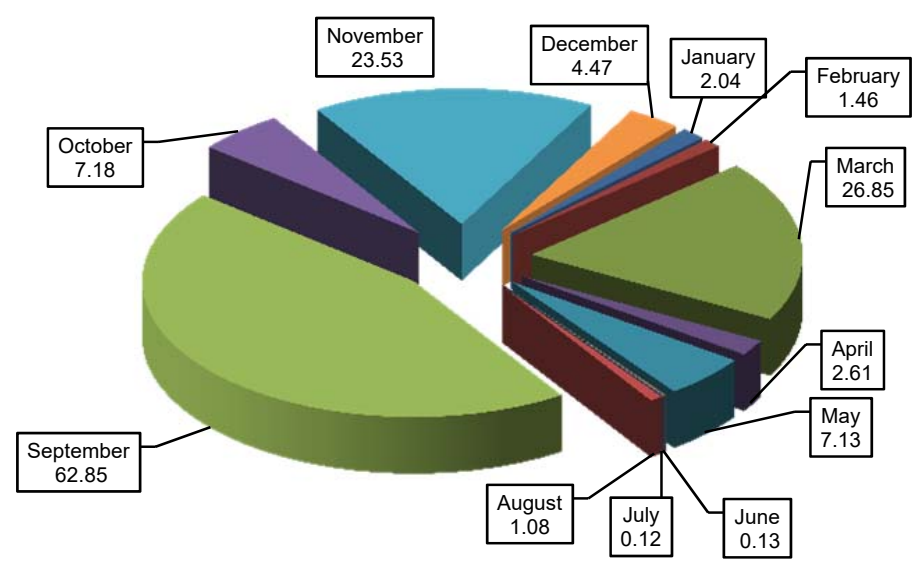

Fig. 7. Monthly contributions of solid concentrations in Tafna basin; source: own study

\section{RESULTS AND DISCUSSION}

The results of adjustment models: solid flow liquid flow are quite significant because the correlation coefficient varies between 86 and 95\% (Tab. 2) for all months except of the month of May where we got a $72 \%$ for correlation coefficient, which confirms that the phenomenon is better identified on a monthly scale. The most significant correlation coefficients are recorded during the months from November to April $(>91 \%)$, this is explained by some regularity of contributions in these months. The lowest coefficients are explained by irregular flows and important intervention of exceptional floods during these months. In general, monthly influence on the phenomenon is visible in this study. The relations between liquid discharge and suspended sediment discharge remains significant in general. The specific degradation of Tafna basin appears very important because it is subjected to climatic and physical conditions highly variable (196.11 Mg $\left.\mathrm{km}^{-2} \cdot \mathrm{yr}^{-1}\right)$ and closest to the results that we found in 1994 in an earlier study on the same watershed (between 197 and 255 $\mathrm{Mg} \cdot \mathrm{km}^{-2} \cdot \mathrm{yr}^{-1}$ ) using previous data to those used in this study (1970-1990) but remains well above the suspended sediment load that we found in the watershed of Wadi Mouillah [BOUCHELKIA et al. 2011] (between 17.73 and $28.41 \mathrm{Mg} \cdot \mathrm{km}^{-2} \cdot \mathrm{yr}^{-1}$ on period 19741999) located in the Tafna basin. This results is higher than the result found by TERFOUS et al. [2001] for the watershed of Mouillah $\left(126 \mathrm{Mg} \cdot \mathrm{km}^{-2} \cdot \mathrm{yr}^{-1}\right.$ in a study period from 1977 to 1993 ), and even it is far from the value obtained by MEGNOUNIF et al. [2003] for specific degradation in one sub-basin in Tafna using data on five years of observation $\left(1120 \mathrm{Mg} \cdot \mathrm{km}^{-2} \cdot \mathrm{yr}^{-1}\right)$, but it should be noted that their estimate does not account for frequency rates liquids.

It is noted that in March the solid contributions are the most important $\left(671.59 \cdot 10^{3} \mathrm{Mg}\right)$ and represent $57.55 \%$ of the contributions in this month because the liquid flows are more regular and more important and floods are more frequent that other months.

\section{CONCLUSIONS}

This estimation approach will allow the projector and the manager of hydraulic structures to better estimate sediment transport and predict the losses in capacity. This approach was applied to quantify the suspended sediment load at the Pierre du Chat station located at the outlet of the watershed of Tafna during the period 1997-2011.

The estimate was based on average daily flow rates in the same for liquid discharge and for the couples liquid discharge - sediment discharge (for the model $\left.Q_{S}=f(Q)\right)$ registered during the period in ques- 
tion. The quantification of suspended sediment yield of Tafna basin has been conducted by monthly scale and based on liquid discharges and theirs frequencies.

The obtained results showed that the sediment load in winter is the most abundant and the most regular. They show that the watershed Tafna has a very important erodability, because the value of solid con-

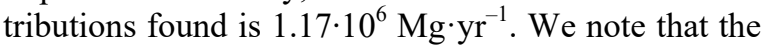
specific degradation found of Tafna basin (196.11 $\left.\mathrm{Mg} \cdot \mathrm{km}^{-2} \cdot \mathrm{yr}^{-1}\right)$ is below the values advanced by PROBST and AMIOTTE-SUCHETT [1992] and WALLING [1984] for the Maghreb, respectively from 420 to 504 $\mathrm{Mg} \cdot \mathrm{km}^{-2} \cdot \mathrm{yr}^{-1}$ and between 1000 and $5000 \mathrm{Mg} \cdot \mathrm{km}^{-2} \cdot \mathrm{yr}^{-1}$.

Considering the results of our previous study on the same watershed we see that the degradation of this basin has accentuated this last twenty years although fluid discharge have declined decreased (drought and construction of two dam "Hammam Boughrara and Sekkak"); This accentuation is probably caused by important changes undergone by this basin in this period especially forest fires.

The results of this study can be used as a simple and directly applicable for estimating solid contributions on all Algerian watersheds. But, a comparison of these results with experimental measurements and on field, will allow us to check the reliability of our results.

\section{REFERENCES}

AChite M., MedDi M. 2004. Estimation du transport solde dans le bassin versant de l'oued Haddad (Nord-Ouest Algérien) [Estimation of sediment transport in the watershed of Wadi Haddad (North-West Algeria)]. Sécheresse. Vol. 15(4) p. 367-373.

ACHITE M., MedDI M. 2005. Variabilité spatio-temporelle des apports liquid et solide en zone semi-aride: Cas du bassin versant de l'oued Mina (nord-ouest algérien) [Spatio-temporal variability of liquid and solid contributions in semiarid area: A case study of Wadi Mina catchment (North-West of Algeria)]. Revue des sciences de l'eau. Vol. 18 p. 37-56.

AChite M., Ouillon S. 2007. Suspended sediment transport in a semiarid watershed, Wadi Abd, Algeria (1973-1995). Journal of Hydrology. Vol. 343 p. 187202.

ARABI M. 1991. Influence de quatre systèmes de production sur le ruissellement et l'érosion en milieu montagnard méditerranéen algérien [Influence of four production systems on runoff and erosion in Algerian Mediterranean montane environment]. $\mathrm{PhD}$ Thesis. Université de Grenoble pp. 276.

Balla F., Kabouche N., Khanchoul K., Bouguerra H. 2017. Hydro-sedimentary flow modelling in some catchments Constantine highlands, case of Wadis Soultez and Reboa (Algeria). Journal of Water and Land Development. No. 34 p. 21-32. DOI 10.1515/jwld2017-0035.

BELARBI F. 2010. Etude de la pluviométrie journalière dans le bassin versant de la TAFNA [Study of daily rainfall in TAFNA catchment]. Mémoire de magister en hydraulique. Département d'hydraulique. Université de Tlemcen, Algérie pp. 113.

Berghout A., Meddi M. 2016. Sediment transport modelling in wadi Chemora during flood flow events. Journal of Water and Land Development. No. 31 p. 23-31. DOI 10.1515/jwld-2016-0033.

BOUANANI A. 2005. Hydrologie, transport solide et modélisation, Etude de quelques sous bassins de la Tafna (NW - Algérie) [Hydrology, sediment transport and modeling, Study of some subcatchments in Tafna (NW - Algeria)]. PhD Thesis. Département d'hydraulique, Université de Tlemcen pp. 250.

BouChELKIA H. 2009. Etude du transport solide dans le bassin versant et son impact sur l'envasement des barrages - cas du bassin versant de Chellif [Study of sediment transport in watershed and its impact on siltation of dams - case of the Chellif watershed]. $\mathrm{PhD}$ Thesis. Université de Tlemcen, Algérie pp. 166.

Bouchelkia H., Belarbi F., Remini B. 2011. Quantification du transport solide en suspension par analyse statistique: cas du bassin-versant de l'oued Mouillah [Quantification of suspended sediment yield by statistical analysis: The case of Mouillah watershed]. Le Journal de l'Eau et de l'Environnement. No. 19 p. 29-41.

Bouchelkia H., Belarbi F., Remini B. 2013. Estimated flows a solid suspended by the statistical analysis of outfall drainage basin of Tafna (Algeria). Soil and Water Research (SWR). Vol. 8(2) p. 63-70.

Bouchelkia H., Belarbi F., REMINI B. 2014. Quantification of suspended sediment load by double correlation in the watershed of Chellif (Algeria). Journal of Water and Land Development. No. 21 p. 39-46.

BouChelkiA H., REMINI B. 2003. Quantification du transport solide dans le bassin versant algérien du Chellif [Quantification of sediment transport yield in the Algerian basin of Chellif]. Ingénieries. No. 33 p. 45-56.

BouZERIA H., GHENIM A.N., KHANCHOUL K. 2017. Using artificial neural network (ANN) for prediction of sediment loads, application to the Mellah catchment, northeast Algeria. Journal of Water and Land Development. No. 33 p. 47-55. DOI: 10.1515/jwld-2017-0018.

Bowker A.H., Lieberman G.J. 1965. Méthodes statistiques de l'ingénieur [Engineering statistics]. DONUD. Paris. pp. 516.

ChOw V.T. 1988. Applied hydrology. Singapore. McGrawHill. ISBN 0070108102 pp. 572.

Demmak A. 1982. Contribution à l'étude de l'érosion et des transports solides en Algérie septentrionale [Contribution to the study of erosion and sediment transport in Northern Algeria]. PhD Thesis. Université de Pierre et Marie Curie. Paris XI, France pp. 323.

Elahcene O., Remini B. 2009. Corrélation entre la concentration en matière en suspension et le débit liquide dans le bassin versant de l'oued Bellah (Algérie) [Correlation between suspended sediment concentration and water discharge in the Wadi Bellah Watershed (Algeria)]. European Journal of Scientific Research. Vol. 26 p. 139-146.

Elahcene O., Terfous A., Remini B., Ghenaim A., Poulet J.P. 2013. Etude de la dynamique sédimentaire dans le bassin versant de l'Oued Bellah (Algérie). Hydrological Sciences Journal. Vol. 58 (1) p. 224-236. DOI $10.1080 / 02626667.2012 .742530$.

Ghenim A., Seddini A., Terfous A. 2008. Variation temporelle de la dégradation spécifique du bassin versant de l'Oued Mouilah, Nord-Ouest algérien [Temporal variation in specific degradation of the Wadi Mouilah watershed, Northwest Algeria]. Hydrological Sciences Journal. Vol. 53. No. 2 p. 448-456. DOI 10.1623/ hysj.53.2.448.

Gliz M., Remini B., Anteur D., Makhlouf M. 2015. Vulnerability of soils in the watershed of Wadi El Hammam 
to water erosion (Algeria). Journal of Water and Land Development. No. 24 p. 3-10.

Khanchoul K., Boukhrissa Z.E., Majour H. 2012. Statistical modelling of suspended sediment transport in the Cherf drainage basin, Algeria. Comunicações Geológicas. Vol. 99. No. 1 p. 27-32.

LEFORT P. 1992. Cours de transport solide dans le lit des cours d'eau [Course of sediment transport in bed of rivers]. Grenoble. National Polytechnic Institute of Grenoble pp. 92.

Madani Cherif H., Terfous A., Bouanani A., GHenim A. 2012. Variability of streamflow and sediment yields in wadi Taria (Northwest Algeria). Sixteenth International Water Technology Conference. IWTC 16 2012, Istanbul (Turkey) p. 1-15.

Megnounif A., Terfous A., Bounanani A. 2003. Production et transport des matières solides en suspension dans le bassin versant de la Haute Tafna (Nord-Ouest Algérien) [Production and transport of suspended sédiment transport in the Upper-Tafna river bassin (North West Algeria)]. Revue des Sciences de l'Eau. Vol. 16(3) p. 369-380.

Megnounif A., Terfous A., Ghenim A., Poulet J.B. 2007. Key processes influencing erosion and sediment transport in a semiarid Mediterranean area: the Upper Tafna catchment, Algeria. Hydrological Sciences Journal. Vol. 52. No. 6 p. 1271-1284. DOI 10.1623/ hysj.52.6.1271.

MusY A. 1998. Hydrologie appliquée [Applied hydrology]. Bucarest. H.G.A. ISBN 973-98530-8-0 pp. 366.

Probst J.L., Amiotte-Suchet P. 1992. Fluvial suspended sediment transport and mechanical erosion in the Maghreb (North Africa). Hydrological Sciences Journal. Vol. 37 p. 621-637.

REMINI B. 1997. Envasement des retenues de barrages en Algérie: importance, mécanismes et moyen de lutte par la technique du soutirage [Silting of dams in Algeria: importance, mechanisms and means of control by the technique of racking] $\mathrm{PhD}$ Thesis. École nationale polytechnique d'Alger pp. 342.

REMINI B. 2004. Sédimentation des barrages en Algérie [Sedimentation of dams in Algeria]. Revue Internationale La Houille Blanche. No. 1 p. 1-5.
Remini B., Bensafia D., NASRoun T. 2015. Impact of sediment transport of the Chellif River on silting of the Boughezoul reservoir (Algeria). Journal of Water and Land Development. No. 24 p. $35-40$

Remini B., Hallouche W., Achour B. 2009. L'Algérie: Plus d'un siècle d'envasement des barrages. Chapitre 8 . In: Etat des ressources en eau au Maghreb [Algeria: More than a century of silting dams. Chapter 8. In: State of Maghreb Water Resources]. UNESCO Office in Rabat p. 123-142.

Tachi S.E., Ouerdachi L., Remaoun M., Derdous O., Boutaghane H. 2016. Forecasting suspended sediment load using regularized neural network: Case study of the Isser River (Algeria). Journal of Water and Land Development. No. 29 p. 75-81. DOI 10.1515/jwld-20160014.

Terfous A., Megnounif A., Bouanani A. 2001. Etude du transport solide en suspension dans l'oued Mouilah (Nord ouest Algérien) [Study of the suspended load at the river Mouilah (North West Algeria)]. Revue des Sciences de l'Eau. Vol. 14(2) p. 173-185.

Selmi K., Khanchoul K. 2016. Sediment load estimation in the Mellegue catchment, Algeria. Journal of Water and Land Development. No. 31 p. 129-137. DOI 10.1515/jwld-2016-0044.

UNESCO 1986. Problème d'érosion, transport solide et sédimentation dans les bassins versants. In: Projet 5.3 du programme hydrologique international [Sedimentation problems in river basins]. Report prepared under the Chairmanship of A. Saudbarg, W.R. White. The United Nations. ISBN 92-3-202014-9 pp. 161.

WALLING D.E. 1984. The sediment yield of African rivers. In: Challenges in African hydrology and water resources. Ed. D.E. Walling, S.S.D. Foster, P. Wurzel. Proceedings of Harare Symposium, July 1984. IAHS Publication pp. 144.

Zettam A., Taleb A., Sauvage S., Boithias L., Belaidi N., Miguel SÁnCHEZ-PÉrez J. 2017. Modelling hydrology and sediment transport in a semi-arid and anthropized catchment using the SWAT model: The case of the Tafna River (Northwest Algeria). Water. Vol. 9. Iss. 3 (216). DOI 10.3390/w9030216.

\section{Fadila BELARBI, Hamid BOUCHELKIA, Boualem REMINI, Abdelhalim BENMANSOUR}

\section{Ilościowa ocena i analiza miesięcznej zmienności ladunku zawiesiny w basenie Tafna w Algierii}

\section{STRESZCZENIE}

Rozmiary sedymentacji są nieporównywalne w klimacie półpustynnym i umiarkowanym. Algieria jest jednym z państw dotkniętych tym procesem i jego skutkami. Aby zapewnić szybką reakcję na wymagania inżynierów i zarządców co do ilościowej oceny transportu osadu, na odpływie ze zlewni skonstruowano proste i łatwe w użyciu narzędzie nadające się do wdrożenia. Przyjęte zasady opierają się na zestawie danych hydrometrycznych z posterunków pomiarowych z użyciem sezonowych i rocznych kroków czasowych w celu zdefiniowania odpowiedniej metody do oceny produkcji osadu. Badania prowadzono, analizując dobowe przepływy. Przykładem był posterunek Pierre du Chat zamykający zlewnię Tafna. Uzyskane wyniki są w pełni satysfakcjonujące, ponieważ współczynnik korelacji modelu $Q_{s}=f(Q)$ wynosił od 72 do 95\%. Przedstawiona metoda, po udoskonaleniu, może zostać uogólniona na wszystkie zlewnie w północnej Algierii.

Słowa kluczowe: erozja, rzeka Tafna, statystyka, transport osadu, zawiesina, zlewnia 